\title{
PENGUATAN HUKUM MASYARAKAT DI ERA OTONOMI DAERAH
}

\author{
Eny Kusdarini
}

Dosen Politik Hukum di Jurusan Pendidikan Kewarganegaraan dan Hukum FISE UNY

\section{Abstract}

Development of law witbin buman dan societal life is influnced by many factors, wether inside of the society itself or from outside. In National politics of law of a country included Indonesia some changes bappen and influence application the law. After Indonesian reform, regulation on local autonomy which is broad, tangible, and accountable needs reinforement of law among society in its application. It is ungently neccessary according to the principles of that the essence of democracy is from, by, and for the people. Reinforcement of societal law will be effective if there was effort to empower society by means of atmosphere or climate which enables the development of potentials of it. It will be if there is an attempt to protect weak society from being weaker.

Keywords: Reinforement of Law, Local Autonomy

\section{Pendahuluan}

Hukum muncul dalam pengalaman hidup setiap orang. Menurut pengalaman itu, hukum pertama-tama muncul sebagai kaidah-kaidah yang mengatur hidup bersama manusia. Kaidah-kaidah tersebut ada yang berbentuk perintah dan larangan. Kaidah-kaidah itu ada yang tertulis dan ada yang tidak tertulis dan selalu muncul dalam kehidupan masyarakat dan mempunyai makna yang luas sekali, mencakup bidang-bidang kehidupan manusia.

Berkembangnya hukum di dalam kehidupan manusia dan masyarakatnya dipengaruhi oleh berbagai faktor. Faktor-faktor yang mempengaruhi hukum tersebut bisa berasal dari dalam masyarakat dimana hukum itu berlaku, bisa juga berasal dari luar masyarakat di mana hukum itu berlaku. Apabila hal tersebut kita kaitkan dengan suatu negara, faktor-faktor yang mempengaruhi berlakunya hukum bisa berasal dari dalam negara itu sendiri bisa juga berasal dari luar negara di mana hukum itu berlaku. Faktor-faktor yang mempengaruhi berlakunya hukum itu selalu berkembang sesuai dinamika perkembangan masyarakat. Pengaruh tersebut 
termasuk pengaruh dari globalisasi yang mencuat akhir-akhir ini dan tidak bisa kita bendung arusnya sehingga mau tidak mau kita juga terseret di dalamnya. Oleh karena itu penguatan hukum masyarakat kita juga dipengaruhi oleh merebaknya issue-issue globalisasi. Memang dalam kenyataannya secara sosiologis keberadaan suatu masyarakat tidak mengenal batas-batas tertentu, apalagi dewasa ini dengan perkembangan teknologi informasi yang begitu cepat informasi yang berasal dari berbagai belahan dunia tidak terpaut dalam hitungan beberapa waktu langsung bisa diterima oleh berbagai masyarakat di dunia.

Realitas nasional yang terjadi di dalam suatu masyarakat juga amat mempengaruhi penguatan hukum masyarakat. Realitas nasional itu baik dilihat dari kondisi historis bangsa yang bersangkutan maupun tradisi-tradisi yang ada di dalam mayarakat itu sendiri dan juga faktor-faktor intern lainnya yang ada di dalam suatu masyarakat.

Di dalam tulisan berikut akan dikaji kaitan antara penguatan hukum masyarakat dengan demokrasi, penguatan hukum masyarakat dalam pelaksanaan otonomi daerah, dan kaitan antara otonomi daerah dengan penguatan hukum masyarakat dan pemberdayaan masyarakat. Perspektif dalam kajian ini akan dilakukan dengan melihat faktor-faktor yang mempengaruhi politik hukum di Indonesia, baik faktor yang berasal dari dalam masyarakat Indonesia sendiri maupun faktor-faktor dari luar masyarakat Indonesia dikarenakan adanya globalisasi.

\section{Kaitan Antara Penguatan Hukum Masyarakat dengan Demokrasi}

Terjadinya penguatan hukum masyarakat erat kaitannya dengan terwujudnya masyarakat warga (civil society). Menurut Soetandyo Wignyosoebroto dalam makalahnya “ Mengupayakan Terwujudnya Masyarakat Warga Di Desa-desa Sebuah Cita-cita Berikut Tantangannya”, penguatan hukum masyarakat merupakan hasil penginggrisan kata istilah societas civilis yang di Indonesia lazim diterjemahkan ke dalam kata istilah "masyarakat sipil atau masyarakat warga", serta yang semula di Malaysia diterjemahkan ke dalam kata istilah "masyarakat madani”. Masyarakat seperti itu adalah suatu model kehidupan bermasyarakat yang terlahir sebagai hasil transformasi dan reformasi yang terjadi sepanjang sejarah kehidupan bangsabangsa barat. Apabila masyarakat madani yang seperti digambarkan ini terealisir maka akan mengakibatkan pula timbulnya penguatan hukum masyarakat.

Sebagai salah satu negara yang sedang berkembang, Indonesia berusaha untuk membangun negara. Apalagi negara kita termasuk salah satu negara yang masih muda, baru mendapatkan kemerdekaan sekitar lebih kurang 60 tahun. Dikarenakan Indonesia merupakan bekas negara jajahan maka hukum-hukum yang berlaku di 
Indonesia banyak yang merupakan warisan-warisan penjajah, terutama peninggalan jaman penjajahan Belanda dikarenakan kita berada dalam penjajahan Belanda lebih kurang tiga setengah abad. Pada saat ini ada dualisme hukum di Indonesia, yakni hukum tertulis yang kebanyakan merupakan hukum barat, walaupun tidak semua hukum barat itu berasal dari Eropa Kontinental, ada sebagian hukum barat yang berasal dari Anglo Saxon, seperti hukum-hukum tentang hak milik intelektual. Di samping hukum barat, hukum nasional yang dibuat setelah Indonesia merdeka, di Indonesia juga berlaku hukum adat yang saat ini dengan berlakunya otonomi daerah, mulai ada kecenderungan kemunculan tumbuh kembangnya hukum adat yang selama ini terpinggirkan akibat penjajahan dan pemerintahan yang sentralistik.

Melacak akar dan sejarah demokrasi, P.J Soewarno dalam makalah "Demokrasi di Indonesia : Melacak Akar dan Sejarahnya" mengatakan bahwa dalam literatur orang mengenal bahwa demokrasi berasal dari Yunani kuno yaitu pemerintahan yang berkembang di polis Athena atau kota Athena. Di kota itu dikatakan bahwa pemerintahan dilakukan sesuai kehendak warga kota yang berkumpul di forum (pasar). Jadi semua warga kota berkumpul di bawah seorang primus inter pares untuk merumuskan kehendaknya, setelah itu mereka memilih orang-orang di antara mereka untuk melaksanakan kehendak yang sudah dirumuskan itu. Oleh karenanya pemerintahan itu disebut demokrasi yaitu pemerintahan oleh rakyat, karena yang dijadikan pedoman adalah kehendak rakyat. kemudian lewat kekaisaran Romawi pemerintahan itu berubah menjadi monarkhi yang berlaku pemerintahan raja berdasarkan Hak Ilahi sampai abad ke 17. Pada waktu itu di Inggris mulai dikenal faham demokrasi dalam pemerintahan lewat Parliament nya. Amerika Serikat dan Perancis mengenal demokrasi lewat lewat revolusi yang terjadi tahun 1789.

Di Indonesia demokrasi modern baru dikenal pada awal abad ke- 20 dan pada tahun 1918 disimulasikan dalam Volsraad. Demokrasi di Indonesia ini yang dimaksud adalah demokrasi barat yang melalui Belanda dibawa ke negara jajahannya termasuk Hindia Belanda. Dalam perkembangannya demokrasi di Indonesia itu merupakan demokrasi yang sudah berlaku cukup lama dan dalam skala yang cukup luas yang membawahkan desa-desa di seluruh Indonesia, yang berasal dari kerajaankerajaan Hindu yang kemudian dicampuri dengan kerajaan Islam, yang kemudian ditumpangi dengan birokrasi modern yang diciptakan oleh Belanda untuk menghisap kekayaan Indonesia. Pengaruh penjajahan Belanda ini terlihat sampai sekarang bahwa pemerintahan yang seharusnya dari rakyat dan untuk rakyat ini masih belum dapat dilaksanakan sebagaimana mestinya. Satjipto Rahardjo (1979 : 145-146), menyatakan bahwa apabila kita berusaha untuk menelusuri perkembangan citra pemerintahan dalam arti yang fundamental yakni dilihat 
sebagai suatu kegiatan yang melibatkan masalah penggunaan kekuasaan, maka dapat pula dirasakan betapa panjang sesungguhnya jalan yang harus dilalui oleh bangsa Indonesia. Tidak sejak semula bangsa Indonesia melihat pemerintahan itu sebagai suatu penerapan kekuasaan untuk memperoleh tujuan-tujuan yang dikehendaki oleh pihak yang memerintah hubungan antara yang memerintah dan yang diperintah sebagaimana kita lihat sekarang ini dan diterima sebagai suatu hal yang tidak perlu dipersoalkan lagi, sesungguhnya merupakan hasil dari suatu perkembangan juga.

Apabila kita lihat dan cermati pada fase perkembangan bangsa Indonesia seperti apa yang dikemukakan Satjipto Rahardjo ini merupakan fase di mana belum terlihat adanya penguatan hukum masyarakat di Indonesia. Pikiran-pikiran rakyat ini masih terlihat belum bebas menentukan pilihan-pilihan dalam kehidupan berbangsa dan bernegaranya, yang diakibatkan oleh berbagai faktor, yang sampai sekarang ini masih membelenggu bangsa Indonesia walaupun sudah terlihat akan mengarah kepada adanya penguatan hukum masyarakat. Akan tetapi menurut Muladi, sebagaimana dikutip oleh HE Zainal Abidin dalam makalahnya "Relevansi Proses Globalisasi Dengan Politik dan Hukum Nasional” untuk sampai ke sana perlu suatu kondisi yang masyarakat yang demokratis dengan ciri-ciri :

1. Ada keterlibatan warga negara dalam pengambilan keputusan;

2. Adanya persamaan atau equality;

3. Adanya perlindungan hak-hak dasar manusia;

4. Adanya sistem perwakilan;

5. Pemerintahan berdasarkan hukum atau rule of law;

6. Sitem pemilihan yang menjamin pemerintahan mayoritas;

7. Pendidikan masyarakat yang memadai.

Di dalam kaitannya dengan konsep negara demokrasi di mana dijamin adanya perlindungan atas kebebasan serta hak-hak azasi manusia (HAM)), menurut H.E. Zainal Abidin maka perlindungan HAM di Indonesia menjadi masalah yang penting, sehingga pemerintah membentuk Komisi Hak Azasi Manusia secara nasional yang antara lain bertugas memantau, mempelajari dan menyampaikan laporan serta saran-saran kepada pemerintah dalam penanganan masalah-masalah yang berkaitan dengan HAM di Indonesia. Konsep demokrasi tersebut akan mencakup tidak hanya demokrasi politik (political democracy) yang berkaitan dengan pemilihan umum, kepartaian, badan legislatif, tetapi juga demokrasi pembangunan dalam arti yang luas (developmental democracy) yang mengatur persamaan kesempatan, pemberdayaan masyarakat, distribusi kesejahteraan, hubungan sipil militer dan sebagainya yang semuanya merupakan "the real markers of democracy". Proses 
demokrasi pembangunan dalam arti yang luas ini diharapkan bisa mengantarkan bangsa Indonesia menuju ke penguatan hukum masyarakat.

Ada berbagai faktor yang bisa mempengaruhi berjalannya penguatan hukum masyarakat. Faktor-faktor tersebut baik yang berasal dari dalam negeri sendiri maupun faktor-faktor yang berasal dari luar yang muncul sangat kuat bersamaan dengan munculnya issue-issue globalisasi. Sebagai contoh diberlakukannya UU Antiterorisme di Indonesia yang diakibatkan oleh issue-issue terorisme dunia, walaupun sebetulnya definisi mengenai terorisme itu sebetulnya belum jelas. Contoh lain adalah diberlakukannya ketentuan-ketentuan hukum mengenai HAKI yang sebetulnya nilai-nilai yang terkandung di dalamnya tidak sesuai dengan nilainilai yang ada pada bangsa kita. Falsafah yang mendasari HAKI adalah nilai-nilai individual, sedangkan nilai-nilai hak berkaitan dengan hak milik di negara kita bersifat komonal, sebagai contoh masyarakat kita masih menganggap bahwa apabila lita dapat membuat kreasi-kreasi baru misalnya di bidang kerajinan mereka beranggapan bahwa ciptaan-ciptaan itu bisa ditularkan kepada orang-orang lain karena di samping akan mendapat balasan dari Tuhan juga masyarakat kita masih mengedepankan nilai-nilai sosial. Hal ini bertentangan dengan falsafah HAKI yang bersifat individual.

Globalisasi ini memberikan pengaruh yang cukup kuat dalam berlakunya demokrasi di Indonesia yang sebetulnya akan mulai nampak tumbuh lagi di Indonesia setelah sekian puluh tahun berada dalam rezim otoriter. Globalisasi adalah karakteristik hubungan antara penduduk bumi yang melampoi batas-batas konvensional, seperti bangsa dan negara. Di dalam proses tersebut dunia telah dimampatkan serta terjadi intensifikasi keșadaran terhadap dunia sebagai satu kesatuan. Globalisasi sebagai suatu proses memang mengalami akselerasi sejak beberapa dekade terakhir ini, akan tetapi proses yang sesungguhnya sudah berlangsung sejak lama, semata-mata karena adanya predisposisi umat manusia untuk bersama-sama hidup di satu wilayah dan karena itu dikondisikan untuk berhubungan dan menjalin hubungan satu sama lain.

Sementara itu Satjipto Rahardjo(1997 : 1-3) mengemukakan bahwa globalisasi sebagai suatu proses memang mengalami akselerasi sejak beberapa dekade ini, tetapi proses yang sesungguhnya sudah berlangsung sejak jauh di masa silam, semata-mata karena adanya predisposisi umat manusia untuk bersama-sama hidup di satu wilayah dan karena itu dikondisikan untuk berhubungan dan menjalin hubungan satu sama lain. Satjipto Rahardjo, juga mengutip pendapat Wallerstein, salah seorang pemikir penting tentang globalisasi yang menyatakan bahwa globalisasi adalah proses pembentukan sistem kapitalis dunia, di mana seiring 
dengan pembentukan sistem tersebut kapitalisme menjadi semakin kuat. Masyarakat-masyarakat di dunia memainkan peranannya di dalam sistem kapitalis dunia tersebut sebagai konsekuensi dari tempatnya dalam pembagian kerja sistemik yang mendunia. Hubungan-hubungan politik dan militer memancar dari hubungan ekonomi yang bersifat mendasar, sedangkan kebudayaan, agama, berada pada posisi pinggiran. Melihat ke dalam sejarah, maka hubungan-hubungan sebagaimana dikemukakan oleh Wallerstein tersebut muncul dalam berbagai bentuk seperti penjajahan. Penjajahan juga merupakan suatu bentuk hubungan antar satuan kehidupan di dunia, di mana bangsa yang satu menguasai kehidupan bangsa yang lain. Bangsa jajahan yang semula otonom terseret ke dalam suasana global melalui berbagai benturan yang kemudian menguasai dan menjajahnya. Di abad ke dua puluh memasuki awal bad ke dua puluh satu ini, di mana penjajahan dalam konotasi konvensional yakni bangsa yang satu menduduki wilayah bangsa yang lain menjadi barang tabu, bangsa-bangsa di dunia terseret ke dalam arus globalisasi melalui pembagian kerja ekonomi kapitalis yang lain, seperti terbentuknya WTO, APEC dan lain sebagainya juga pengaruh issue-issue lainnya yang kemudian menekan suatu bangsa untuk mengikuti arus tersebut seperti yang telah digambarkan diatas mengenai issue terorisme dunia yang kemudian mempengaruhi kehidupan bangsa kita dengan tekakanan untuk memberlakukan UU Anti terorisme.

Menurutnya sosiologi sebenarnya tidak mengenal batas-batas bengsa/negara, semata-mata karena ia bukan ilmu normatif, melainkan deskriptif-eksplanatoris. Satuan kajian sosiologi adalah masyarakat atau kehidupan bersama manusia, dan itu tidak mengenal batas. Apabila ia berhadapan dengan kenyataan satuan kehidupan yang disebut bangsa/negara, maka ia akan memasukkannya ke dalam kategori sosiologi komparatif. Satjipto Rahardjo juga mengemukakan bahwa globalisasi sebagai suatu proses memang mengalami akselerasi sejak beberapa dekade ini, tetapi proses yang sesungguhnya sudah berlangsung sejak jauh di masa silam, semata-mata karena adanya predisposisi umat manusia untuk bersama-sama hidup di satu wilayah dan karena itu dikondisikan untuk berhubungan dan menjalin hubungan satu sama lain. Menurutnya sosiologi sebenarnya tidak mengenal batasbatas bengsa/negara, semata-mata karena ia bukan ilmu normatif, melainkan deskriptif-eksplanatoris. Satuan kajian sosiologi adalah masyarakat atau kehidupan bersama manusia, dan itu tidak mengenal batas. Apabila ia berhadapan dengan kenyataan satuan kehidupan yang disebut bangsa/negara, maka ia akan memasukkannya ke dalam kategori sosiologi komparatif.

Setelah melihat uraian di muka, dapat dikatakan bahwa penguatan hukum masyarakat dalam rangka demokrasi di Indonesia tidak bisa melepaskan diri dari pengaruh-pengaruh dunia luar. Hal ini terjadi karena di dalam kehidupan bersama 
manusia/masyarakat tidak bisa kita mengisolasi diri, dan seperti apa yang dikemukakan oleh Satjipto Rahardjo bahwa secara sosiologis masyarakat tidak mengenal batas. Demikian juga penguatan hukum masyarakat dalam proses demokrasi di Indonesia dipengaruhi juga oleh situasi-situasi yang terjadi di dunia internasional dikarenakan kehidupan masyarakat termasuk dalam hal penguatan hukum masyarakat tidak bisa dilepaskan dari pengaruh-pengaruh dunia internasional.

\section{Penguatan Hukum Masyarakat Dalam Pelaksanaan Otonomi Daerah}

Setelah berlakunya Undang-undang pemerintahan di daerah yang baru, yang di dalamnya diatur mengenai ketentuan-ketentuan tentang otonomi daerah yang luas, nyata dan bertanggung jawab dan mulai dilaksanakan pada tahun 2001 dengan diundangkannya UU No. 22 Tahun 1999 sebagaimana telah diubah dengan UU No. 32 Tahun 2004, maka mulai ada kecenderungan munculnya tumbuh kembang hukum adat yang selama ini terpinggirkan berlakunya. Kemunculan tumbuh kembangnya hukum adat ini sebetulnya merupakan titik terang dari penguatan hukum masyarakat, di mana kita ketahui bahwa sebetulnya hukum adat itu merupakan hukum yang berasal dari masyarakat Indonesia sendiri dan sudah ada lama sebelum penjajah masuk ke Indonesia. Dikemukakan oleh Satjipto Rahardjo (1979 : 85) bahwa pada waktu pedagang Belanda mengadakan kontak dengan bangsa Indonesia maka mereka berhadapan dengan negara-negara pedalaman (kerajaan-kerajaan), seperti Sriwijaya dan Majapahit di mana negara-negara itu telah menjadi sejarah kejayaan bangsa Indonesia. Bagian-bagian yang membentuk kerajaan tersebut berupa desa-desa yang penduduknya menggantungkan hidup dari persawahan. Tentunya masyarakat-masyarakat desa tersebut telah memiliki hukum-hukumnya yang telah mengakar pada masyarakat yang bersangkutan. Hukum-hukum inilah yang sebagian merupakan hukum adat yang ada di Indonesia.

Zainal Abidin (1997: 11) mengutip pendapat Prof. Soepomo dan Prof. Moh. Koesnoe menyatakan bahwa hukum adat dan Ilmu hukum adat adalah hukum yang sekalipun tidak tertulis akan tetapi hidup dan ditaati dalam kehidupan masyarakat sehari-hari karena memancarkan dan menjelmakan pikiran dan perasaan hukum rakyat yang terus tumbuh dan berkembang bersumber dari jiwa, perasaan dan keyakinan hukum bangsa Indonesia sendiri. Oleh karena itu, pelaksana atau petugas hukum dituntut untuk menguasai dan menghayati segala asas, nilai dan sistem yang hidup di dalam masyarakat agar keputusan-keputusan yang diambil dapat berlaku dan ditaati oleh warga masyarakat. Ilmu hukum adat sebagai embrio hukum nasional perlu diperhatikan, digali, dikembangkan secara ilmiah ke taraf 
hukum modern setaraf dengan teori dan ilmu hukum di negara-negara barat, mempersatukan cita-cita bangsa Indonesia dengan cita-cita dan kebutuhan modern secara harmonis. Cara yang paling efektif adalah melalui asimilasi atau modifikasi pengertian-pengertian barat dalam bentuk yang sesuai dengan struktur masyarakat Indonesia sendiri. Dewasa ini mengutip apa yang dikemukakan Satjipto Rahardjo (1979 : 79) bahwa suatu politik hukum yang baik tentunya tidak akan meninggalkan kenyataan-kenyataan (hukum adat) yang telah ada lama di Indonesia. Walaupun di dalam perkembangan masyarakat terutama masyarakat Indonesia yang diinginkan sebagai masyarakat yang modern berlakunya hukum adat tersebut harus disesuaikan dengan kondisi perkembangan yang ada setelah munculnya wacana mengenai otonomi daerah.

Menurut E. Koswara dalam makalahnya "Otonomi daerah Yang Berorientasi Kepada Kepentingan Rakyat”, krisis ekonomi, politik dan krisis kepercayaan yang berkepanjangan di Indonesia walaupun terasa pahit dan menimbulkan keterpurukan bagi bangsa Indonesia, akan tetapi menumbuhkan juga hikmah positif timbulnya idee dan pemikiran dasar mengenai terwujudnya masyarakat madani (civil society) dalam kehidupan berpemerintahan, bermasyarakat dan bernegara yang memiliki nilai-nilai "a Good Governance" ("Berboorlijk Bestuur") yang memunculkan nilai demokrasi dan sikap keterbukaan, kejujuran (bonesty), keadilan, berorientasi kepada kepentingan rakyat, serta bertanggung jawab (akuntabel) kepada rakyat. Ide ini kemudian memunculkan adanya otonomi daerah yang telah tertuang dalam UU No. 22 Tahun 1999 sebagaimana telah diubah dengan UU No. 32 Tahun 2004 tentang Pemerintahan Daerah, yang meletakkan otonomi kepada daerah seluas mungkin, dan meletakkan fokus otonomi daerah pada tingkat wilayah yang paling dekat dengan rakyat. hal ini di dasarkan pada pemikiran bahwa dalam pelaksanaan otonomi daerah bukan hanya tersimpul makna pendewasaan politik rakyat daerah di mana terwujud peran serta dan pemberdayaan masyarakat, melainkan juga sekaligus bermakna mensejahterakan rakyat. penyebab lain dari pemikiran tersebut adalah karena bagaimanapun juga tuntutan pemerataan, tuntutan keadilan yang sering dilancarkan, baik menyangkut bidang ekonomi maupun politik pada akhirnya akan menjadi fokus utama dalam penyelenggaraan otonomi daerah. Untuk itu diperlukan penguatan hukum masyarakat sehingga harapan untuk terwujudnya peran serta masyarakat dan pemberdayaan masyarakat serta kesejahteraan rakyat akan bisa dicapai. Namun demikian di dalam pelaksanaan otonomi daerah di Indonesia, perlu diingat apa yang dikemukakan oleh E. Koswara bahwa otonomi daerah sebagai perwujudan pelaksanaan asas desentralisasi dalam penyelenggaraan pemerintahan, pada hakekatnya merupakan penerapan konsep teori "areal division of power" yang membagi kekuasaan secara vertikal sesuatu negara. 
Di dalam sistem ini, kekuasaan negara akan terbagi antara "pemerintah pusat" di satu pihak, dan "pemerintah daerah" di lain pihak. Sistem pembagian kekuasaan dalam rangka penyerahan kewenangan otonomi daerah, antara negara yang satu dengan negara yang lain tidak akan sama, termasuk Indonesia yang secara legal konstitusional menganut sistem Negara Kesatuan. Kewenangan otonomi daerah yang menuju kemandirian daerah di dalam Negara Kesatuan, tidak dapat diartikan adanya kebebasan penuh secara absolut dari suatu daerah untuk menjalankan hak dan fungsi otonominya menurut sekehendaknya tanpa mempertimbangkan kepentingan daerah lain dan kepentingan nasional secara keseluruhan.

\section{Kaitan Antara Otonomi Daerah dengan Penguatan Hukum Masyarakat dan Pemberdayaan Masyarakat Di Indonesia}

Otonomi daerah adalah kewenangan daerah otonom untuk mengatur dan mengurus kepentingan masyarakat setempat menurut prakarsa sendiri berdasarkan aspirasi masyarakat (Pasal 1 huruf h dan I UU No. 22 Tahun 1999 tentang Pemerintah Daerah), yang dilaksanakan dengan titik berat pada daerah kabupaten/ kota, sehingga daerah kabupaten/kota ini merupakan daerah otonom. Daerah otonom adalah merupakan kesatuan masyarakat hukum yang mempunyai batas daerah tertentu dan berwenang untuk mengatur serta mengurus kepentingan masyarakat setempat menurut prakarsa sendiri berdasarkan aspirasi masyarakat dalam ikatan Negara Kesatuan Republik Indonesia. Untuk melaksanakan otonomi daerah ini diperlukan pemberdayaan masyarakat di samping adanya penguatan hukum masyarakat.

Otonomi yang diberikan kepada daerah otonom (kabupaten/kota) ini, adalah otonomi yang luas, nyata dan bertanggung jawab. Kewenangan otonomi yang luas ini maksudnya adalah keleluasan daerah untuk menyelenggarakan pemerintahan yang mencakup kewenangan semua bidang pemerintahan, kecuali kewenangan di bidang politik luar negeri, pertahanan keamanan, peradilan, moneter dan fiskal, agama serta kewenangan bidang lainnya yang akan ditetapkan dengan peraturan pemerintah. Keleluasaan otonomi tersebut mencakup pula kewenangan yang utuh dan bulat dalam penyelenggaraannya mulai dari perencanaan, pelaksanaan, pengawasan, pengendalian, dan evaluasi. Dimaksudkan dengan otonomi nyata adalah keleluasaan daerah untuk menyelenggarakan kewenangan pemerintahan di bidang tertentu yang secara nyata ada dan diperlukan serta tumbuh, hidup, dan berkembang di daerah. Sedangkan maksud dari otonomi yang bertanggung jawab adalah berupa perwujudan pertanggung jawaban sebagai konsekuensi pemberian hak dan kewenangan kepada daerah otonom dalam wujud tugas dan kewajiban yang harus dipikul oleh daerah dalam mencapai tujuan 
pemberian otonimi, berupa peningkatan pelayanan dan kesejahteraan masyarakat yang semakin baik, pengembangan kehidupan demokrasi, keadilan, dan pemerataan, serta pemeliharaan hubungan yang serasi antara pusat dan daerah serta antar daerah dalam rangka menjaga keutuhan Negara Kesatuan Republik Indonesia.

Untuk melaksanakan otonomi daerah dengan fokus otonomi pada tingkat wilayah yang paling dekat dengan rakyat ini perlu ditumbuhkan penguatan hukum masyarakat, yang digali dari hukum adat dan kebiasaan-kebiasaan serta nilai-nilai sosial budaya yang sudah ada pada masyarakat setempat, sehingga dengan demikian hukum-hukum tidak tertulis yang berasal dari masyarakat setempat dapat tumbuh dan berkembang lagi seperti keinginan masyarakat yang bersangkutan. $\mathrm{Hal}$ ini perlu dilakukan mengingat hakekat otonomi daerah adalah bukan hanya tersimpul makna pendewasaan politik rakyat daerah di mana terwujud peran serta dan pemberdayaan masyarakat, melainkan juga sekaligus bermakna mensejahterakan rakyat. Untuk itu diperlukan penggalian nilai-nilai yang ada dalam masyarakat agar dapat dipakai sebagai alat untuk memberdayakan masyarakat yang pada akhirnya diharapkan untuk bisa mengantarkan pada kesejahteraan masyarakat setempat. Pemberdayaan masyarakat pada era otonomi daerah amat penting, mengingat bahwa di dalam pelaksanaan otonomi daerah diperlukan kemandirian daerah terutama kemandirian masyarakatnya dalam mengatur dan mengurus rumah tangganya sendiri. Menurut Josef Riwu Kaho (1997: 111-114) salah satu cara untuk meningkatkan kemandirian daerah adalah dengan melibatkan masyarakat untuk ikut serta bertanggungjawab terhadap penyelenggaraan otonomi daerah. Dalam hal ini partisipasi masyarakat difungsikan sebagai substitusi energi pusat dan sebagai sumber energi alternatif bagi daerah, sehingga di dalam pelaksanaan otonomi daerah secara bertahap dapat melepaskan diri dari ketergantungannya pada pusat. Di samping itu sudah semestinya bahwa di dalam partisipasi masyarakat untuk melaksanakan otonomi daerah, masyarakat (rakyat) ditempatkan sebagai sumber kekuasaan dan kedaulatan. Di dalam hal ini juga terkandung makna bahwa untuk menempatkan masyarakat sebagai sumber kekuasaan dan kedaulatan mestinya di dalam partisipasi masyarakat termasuk juga ada penguatan hukum yang sudah ada, tumbuh dan berkembang di dalam masyarakat. $\mathrm{Hal}$ ini perlu dialakukan mengingat bahwa di dalam suatu negara yang demokrasi menghendaki partisipasi masyarakat dan penguatan hukum masyarakat yang didasarkan pada pertimbangan bahwa kedaulatan ada di tangan rakyat yang melaksanakannya melalui kegiatan bersama untuk menetapkan tujuan serta masa depan masyarakat itu termasuk juga untuk menentukan orang-orang yang akan memegang tampuk pinpinan untuk masa berikutnya. Pertimbangan ini juga merupakan esensi dari suatu negara yang demokratis, karena konsepsi partisipasi masyarakat ini terkait 
secara langsung dengan ide demokrasi di mana prinsip dasar demokrasi adalah "dari, oleh dan untuk rakyat". Semestinya ide ini akan memberikan pada setiap rakyat (warga negara) kemungkinan untuk menaiki jenjang atas skala sosial dan dengan demikian menurut hukum membuka jalan bagi hak-hak masyarakat untuk meniadakan semua hak iśtimewa yang dibawa sejak lahir. Dapat juga dikatakan bahwa prinsip ini bertujuan untuk menjamin pengaruh dan partisipasi yang sama dalam mengatur kepentingan bersama bagi semua masyarakat.

Pemberdayaan masyarakat mengandung arti bahwa ada kemampuan individuindividu yang bersenyawa dalam masyarakat dan membangun keberdayaan masyarakat yang bersangkutan. Masyarakat dengan tingkat keberdayaan yang tinggi adalah masyarakat yang sebagian besar anggotanya sehat fisik dan mental, terdidik dan kuat, serta memiliki nilai-nilai intrinsik yang juga menjadi sumber keberdayaan seperti kekeluargaan, gotong royong dan juga kebinekaan. Gunawan Sumodiningrat (1996: 154157) menyatakan bahwa keberdayaan masyarakat adalah unsur-unsur yang memungkinkan suatu masyarakat bertahan (survive) dan dalam pengertian yang dinamis mengembangkan diri dan mencapai tujuan. Keberdayaan masyarakat ini menjadi sumber ketahanan nasional. Sedangkan memberdayakan masyarakat adalah upaya untuk meningkatkan harkat dan martabat lapisan masyarakat kita, atau dengan kata lain, memberdayakan masyarakat adalah meningkatkan kemampuan dan meningkatkan kemandirian masyarakat. Upaya pemberdayaan ini dilakukan melalui tiga jurusan. Pertama, dengan menciptakan suasana atau iklim yang memungkinkan potensi masyarakat berkembang, dengan titik tolak adalah pengenalan bahwa setiap manusia dan masyarakat mempunyai potensi yang dapat dikembangkan. Caranya dengan mendorong, memberikan motivasi, dan membangkitkan kesadaran akan potensi yang dimilikinya termasuk misalnya potensi aturan-aturan hukum yang telah ada di dalam masyarakat setempat. Kedua, memperkuat potensi atau daya yang dimiliki masyarakat (empowering). Ketiga, memberdayakan mengandung pula arti melindungi, sehingga dalam proses pemberdayaan harus dicegah yang lemah menjadi semakin lemah.

Setelah melihat konsep otonomi daerah, penguatan hukum masyarakat dan pemberdayaan masyarakat yang dipaparkan di atas dan hal itu diharapkan dapat dilaksanakan di Indonesia, maka pelaksanaan otonomi daerah yang diinginkan benar-benar akan bisa diwujudkan. Oleh karenanya otonomi daerah di Indonesia mempunyai kaitan erat dengan penguatan hukum masyarakat dan pemberdayaan masyarakat, serta dipengaruhi oleh berbagai faktor perkembangan yang ada di dalam mesyarakat termasuk masyarakat dunia karena akibat dari arus globalisasi yang tidak dapat kita bendung perkembangannya. 


\section{Penutup}

Penguatan hukum masyarakat di era otonomi daerah amat diperlukan karena esensi demokrasi adalah dari, oleh dan untuk masyarakat. Penguatan hukum masyarakat ini bisa terlaksana apabila ada upaya pemberdayaan masyarakat dengan cara menciptakan suasana atau iklim yang memungkinkan potensi masyarakat berkembang, ada upaya empowering, dan ada upaya perlindungan terhadap masyarakat yang lemah agar tidak menjadi bertambah lemah. Setelah adanya upaya pemberdayaan ini diharapkan masyarakat mampu berpartisipasi aktif dalam dalam kegiatan-kegiatan demokrasi termasuk di dalamnya ikut berpartisipasi aktif di dalam pelaksanaan otonomi daerah. Oleh karena itu dapat dikatakan bahwa dalam pelaksanaan otonomi daerah diperlukan penguatan hukum masyarakat, yang dapat digali dari potensi-potensi hukum yang ada di dalam masyarakat itu sendiri, dan hukum tersebut ditumbuhkembangkan agar dapat diberlakukan lagi dengan efektif karena kita tahu bahwa selama ini berlakunya hukum, terutama hukum-hukum yang ada di dalam masyarakat terpinggirkan oleh kedatangan penjajah dan pemerintahan yang selama iini bersifat sentralistik. Perlu diupayakan agar hukumhukum setempat tidak dikesampingkan karena adanya pengaruh-pengaruh dari luar yang bertentangan dengan nilai-nilai dari masyarakat setempat. Hal ini bisa kita pahami mengingat bahwa di dalam otonomi daerah terkandung makna bahwa daerah diberi keleluasaan untuk mengatur daerahnya sendiri dengan mengikutsertakan dan memberdayakan masyarakat setempat dalam aspek-aspek kehidupan demi terwujudnya kesejahteraan rakyat yang ada di daerah tersebut.

Namun demikian harus kita sadari juga bahwa di era globalisasi kita tidak dapat mengisolir diri terhadap pengaruh-pengaruh dari luar yang perkembangannya terlalu cepat dan mau tidak mau kita juga terseret di dalamnya. Pengaruh-pengaruh tersebut juga mempengaruhi berlakunya hukum-hukum kita yang beraneka ragam dari masyarakat-masyarakat setempat, sehingga kadangkadang tidak sesuai dengan nilai-nilai yang mendasari berlakunya hukum di dalam masyarakat Indonesia. Dengan demikian dapat dinyatakan juga bahwa penguatan hukum masyarakat banyak dipengaruhi oleh berbagai faktor, baik faktor yang berasal dari dalam negeri Indonesia sendiri maupun faktor-faktor yang berasal dari luar Indonesia. Pengaruh tersebut harus kita antisipasi supaya tidak menimbulkan gejolak di dalam masyarakat, yang pada akhirnya akan mempengaruhi otonomi daerah yang luas, nyata dan bertanggung jawab yang telah mulai setahap demi setahap diberlakukan di kabupaten/kota di seluruh wilayah Indonesia.["] 


\section{Daftar Pustaka}

E. Koswara, 1999, Otonomi Daerah yang Berorientasi Kepada Kepentingan Rakyat, (makalah) yang disampaikan dalam Seminar/Diskusi/Dialog dalam rangka pengkajian dan sosialisasi UU No. 22 Tahun 1999 di lingkungan Departemen/Universitas/Badan/LSM/Instansi Pusat dan Daerah, Depdagri, Jakarta;

,2000, Pengaruh Format Politik Nasional Terhadap Demokrasi Lokal, (makalah) disampaikan pada Seminar Sehari :Demokrasi Mulai Dari Desa” diselenggarakan oleh LAPERA INDONESIA, Yogyakarta, 25 Januari 2000;

Gunawan Sumodiningrat, 1996,Pembangunan Daerab dan Pemberdayaan Masyarakat, PT Bina Rena Pariwara, Jakarta;

Josef Riwu Kaho, 1997, Prospek Otonomi daerab di Negara Republik Indonesia, cetakan ke IV, Raja Grafindo Persada, Jakarta;

P.J Soewamo, 2000,Demokrasi Desa di Indonesia : Melacak Akar Sejarabnya, (makalah) disampaikan pada Seminar Sehari Demokrasi Mulai Dari Desa yang diselenggarakan oleh LAPERA INDONESIA, di Yogyakarta, 25 Januari 2000;

Satjipto Rahardjo, 1979, Hukum dan Perubaban Sosial, Alumni, Bandung,

, 1997, Pembangunan Hukum Di Indonesia Dalam Konteks Situasi Global, dalam majalah PERSPEKTIF, Juli 1997;

Soetandyo Wignyosoebroto, 2000, Mengupayakan Terwujudnya Masyarakat di DesaDesa Sebuab Cita-Cita Berikut Tantangannya,(makalah)yang disampaikan pada Seminar Sehari Demokrasi Mulai Dari Desa yang diselenggarakan LAPERA INDONESIA di Yogyakarta, 25 Januari, 2000;

Zainal Abidin, 1997,Prospektif Hukum di Indonesia Antara Kontinental dan Anglosakson, (makalah) Program Doktor Ilmu Hukum UNDIP, Semarang; , 1997, Relevansi Proses Globalisasi dengan Politik Hukum Nasional, (makalah) Program Doktor Ilmu Hukum UNDIP, Semarang;

Undang-undang Nomor 22 Tahun 1999 tentang Pemerintah Daerah Undang-undang Nomor 32 Tahun 2004 tentang Pemerintah Daerah 